\title{
In Dystopian Retrospect of a Crisis Mood: $M y$ Life as a Spy by Katherine Verdery
}

\author{
Anca PEIU \\ University of Bucharest (Bucharest, Romania) \\ Department of English \\ anca.peiu@lls.unibuc.ro
}

\begin{abstract}
My essay bears a deliberately oxymoronic title as it offers, on the one hand, a reminiscence of 1984, as a most depressing year in the actual history of Romania and likewise in my own earliest career memories. On the other hand, it proposes a contemplation of George Orwell's British postmodern dystopia Nineteen Eighty-Four (1949). Last but not least, it presents certain 1984 aspects as rendered by the following exceptional book, a great challenge for any scholar of my homeland and my generation: $M y$ Life as a Spy: Investigations in a Secret Police File (2018). Distinguished Professor Katherine Verdery, its author, a contemporary American scholar, belongs now also to our Romanian academic elite. Yet this book testifies to her darkest experience in our country, just before the Iron Curtain fell down. Although the parallel between these two books may seem risky at first sight, they share much more than meets the eye; and my claim endeavors to go beyond this visible pretext of the new COVID-19 pandemic, another crisis which has intruded upon all our lives - just like a spy.
\end{abstract}

Keywords: dystopia, retrospect, Doppelgänger, clone, spy, surveillance, crisis, virus

Motto: "In short, the clone worked much like a virus." (Katherine Verdery, My Life as a Spy, Prologue)

\section{A Crisis Book, Concerning Us All}

By her specialized research achievements and significant contributions to anthropological and ethnographic studies of Transylvania, as now a Doctor Honoris Causa of Babeş-Bolyai University of Cluj-Napoca, American Professor Katherine Verdery is now an authority in Romanian cultural studies. ${ }^{1}$ Yet $M y$

1 Though we are aware of Professor Katherine Verdery's outstanding and universally acknowledged sound contribution to the academic research of the Romanian brand of communism, this is not 
Life as a Spy: Investigations in a Secret Police File (2018), the book that I am approaching here, is a special case that can leave no reader indifferent, whether American or Romanian. It concerns us all, especially at such a time of crisis as today. And here is the first quality that her disquieting volume shares with George Orwell's dystopian novel Nineteen Eighty-Four (1949): little could these two authors guess the ironically prophetic messages once conveyed by their books.

As for the books themselves, no other two books could be more different from each other, in many essential regards, such as the following: one is fiction, the other one is non-fiction; one is a gloomy anticipation, the other one is an endlessly painful memory; one is British, the other one - American. Apparently, for a Romanian (passionate and professional) reader, like myself, these two books should remain at a safe cultural distance from each other. And yet...

What will always fascinate the same reader about both these apparently accessible books is their tragicomic echo. Katherine Verdery's volume starts from this irresistibly funny title: as if any serious spy, still teaching at an American university today, would ever dream of (playfully) sharing publicly some memories from a formerly secret activity. Or just offer some sort of a practical guide in spying/being spied on.

Essentially, like a good postmodern book, My Life as a Spy relies on selfreflexiveness: the late- $20^{\text {th }}$-century "spy" within this book is watching now the (actual) spies all around her; yesterday's spies and spies of today. In a way, there must also be a "spy" at the back of any scholar's mind, never easy to please, always doubting and looking for perfection. Yet what this book depicts in exquisitely vivid imagery, just as familiar to us, besides this restless innermost scholarly "spy", is a world of totalitarian surveillance populated by (in)visible outer spies, whether professionals or amateurs, casually betraying an unsuspecting foreign friend: "It is my hope" - the author promises - "that this book will render visible a certain set of surveillance practices and their effects, in a world in which new forms of surveillance proliferate every day" (Verdery 2018, xii).

This is a singular book to read for a teacher like myself: neither (pure) literature, although continually alluding to it, nor (just) fact; in-between a detectivestory parody (much more fun actually than the classic "Agent 007" series) and some random diary/file notes; from infamous institutionalized gossip to (often affectionate) reminiscence and desperate/enthusiastic letters home and candid fieldwork notes. Last but not least, the substantial photographic evidence of her surveillance and moral abuse. The author's main qualities now are her lucidity

our concern in the present paper.

On the other hand, having read with good profit one of the first and best reviews of My Life as a Spy, i.e. Neal Ascherson's essay "Don't Imagine You're Smarter”, promptly published in the London Review of Books, in the summer of 2018, we consider that the time has come now for a Romanian reader to also comment on the American Professor's informal book about her Romanian experience. 
and convincing sense of humour - both giving a certain stylistic value to this kaleidoscope. Moreover, by detaching herself from the first shock of discovering the almost three thousand pages of the eleven CNSAS ${ }^{2}$ files on her account, Katherine Verdery bears no grudge now to those who once betrayed her. This is what should win over any reader. Plus her genuine narrative gift.

I should say that Edgar Allan Poe belongs, too, in this puzzling picture background, sending us greetings from his William Wilson, the absolute romantic double dealer (anticipating Oscar Wilde's Dorian Gray); and likewise from C. Auguste Dupin, the classic unconventional detective prototype (paving the way for Sir Arthur Conan Doyle’s Sherlock Holmes). Poe's romantic Doppelgänger and his lucid master of ratiocination would keep us good company all through this hallucinating trip led by Katherine Verdery. Yet her Gothic brand may also evoke to us, Romanians, rather homely sites of inspiration: after all, Bram Stoker's Dracula was born in this same Eastern European neighbourhood, the worldfamous fantasy in its original English still haunting some ghostly Transylvanian castle. Nevertheless, I felt grateful for never finding any mention of this one in Katherine Verdery's exquisite book.

\section{The Clone and the Virus}

The Doppelgänger personae in My Life as a Spy can also have surprisingly strong affinities with certain contemporary Romanian representations of the double dealer. Katherine Verdery proves to be a knowledgeable reader of some of our best Romanian authors of today: Herta Müller, Ana Blandiana, Gabriel Liiceanu, or Stelian Tănase, to name just the most frequently quoted in her book. In the early $21^{\text {st }}$ century, now as a reluctant reader of her own eleven files of the Securitate surveillance, all completed while she was doing her earliest scholarly research here, in totalitarian Romania, during the last (and the worst) two decades of communist dictatorship, anthropologist Katherine Verdery shared her bewilderment and disgust first with that confessed by writer Herta Müller, winner of the 2009 Nobel Prize in Literature:

In my file I am two different people. One is called "Cristina", who is being fought as an enemy of the state. To compromise this "Cristina" the falsification workshop of Branch " $\mathrm{D}$ " (disinformation) fabricated a Doppelgänger from all those ingredients that would harm me the most [in her new home in West Germany] - party-faithful communist, unscrupulous secret agent. Wherever I went, I had to live with this Doppelgänger. It was

2 CNSAS - Consiliul Național pentru Studierea Arhivelor Securității (National Council for the Study of the Securitate's Archives). 
not only sent after me wherever I went, it also hurried ahead . . . It has taken on a life of its own. (Verdery 2018, 6-7)

The other important Romanian author whom Katherine Verdery quotes in her Prologue to My Life as a Spy is philosopher Gabriel Liiceanu. This is how he renders his own shocking acquaintance with his "evil twin", as one of moral defilement and annihilation:

This cheap misrepresentation wasn't just bad and ugly. It was also dangerous, because - in the role of "target" that I had been assigned - it had been at the same time aimed against my life. It was my Doppelgänger, my double, ready to eliminate me. It was I, indeed, but an "I" that was negative, an "I-enemy," which in the end would have to be eliminated . . . This Clone from the File recorded and reproduced the cells of the original, but commandeered them according to its own logic. (Verdery 2018, 7; emphasis in the original)

And then the contemporary American scholar's conclusion reads here as a prophecy for our own $21^{\text {st }}$-century version of the classic Roaring Twenties: “In short the clone worked much like a virus. Because the replica would resemble him, the Securitate could readily substitute its fabrication for his 'real' self and change his destiny, making him appear guilty of things that might send him to languish in a Romanian labor camp” (Verdery 2018, 7; my emphasis). Therefore, this devastating experience of actually meeting one's "clone" in some surveillance files resembles an infection with a virus, perverting and eventually murdering its target/source, i.e. the actual self, the actual mind of a human. Just before starting to read them, Verdery's hesitation when confronted with the CNSAS poisoning pile of slanderous files about her is well justified. For the concerned person under the surveillance magnifying glass, just reading such documents is in itself a morbid experience. And against it, no vaccine has yet been discovered. For all its thoroughness, not even the Securitate (or the Romanian-Orwellian Thought Police) could have anticipated the proportions of this living allegory soon to enter our existence. Indeed, the two types of invasion are comparable to each other: that of the murderous virus and that of the Thought Police surveillance. But against this latter kind of traumatic intrusion, one is - if not helpless - obviously less prepared to resist; and hardly ever immune.

Informers and/or spies were ubiquitous in 1984 Romania, just as they were in George Orwell's dystopia Nineteen Eighty-Four. They were omnipresent like a catching disease, poisonous like a perverse infection, and the disheartening atmosphere thus created was quite comparable to what we are nowadays experiencing, obsessively trying to protect ourselves against the insidious virus, 
which can be anywhere in the air or which can be brought by anyone, never quite as harmless as it might seem.

\section{In Point of Language}

Still another Romanian-American book that Verdery's My Life as a Spy reminds me of is The Woman in Red (1990), that "collective novel", thus defined by Martin Adams Mooreville, another American scholar who happened to be in this "Wild East" of ours around the time of that late 1980s crisis, just preceding the official ending of the Cold War. That belated Romanian Jazz Age novel pastiche, put together as an (im)perfect narrative hybrid by three young writers who were - like Katherine Verdery - academics themselves: Mircea Nedelciu, Adriana Babeți, and Mircea Mihăieş, is always accompanied by Martin Adams Mooreville’s 1990 witty Afterword: "Conquering the Wild East". This essay was originally published in The New York Literary Journal on "March 29, 1990, pp. 18-19” (Nedelciu, Babeți, Mihăieş 2011, 497). Martin Adams Mooreville had arrived that far overseas due to a Fulbright scholarship, while Katherine Verdery crossed the Atlantic for a second research interval, in August 1984, by means of an IREX scholarship.

This time, what brings the two books together, the American non-fiction volume and the Romanian novel, despite their obvious difference in structure, again, is their (meta)linguistic in-betweenness. The Woman in Red is quite a challenge for any ambitious literary translator, mainly because of its "free" blend of early- $20^{\text {th }}$ century oral Romanian (as spoken in Banat, a cultural zone actually including, on a realistic map, Verdery's Hunedoara, her first ethnographic research zone) and colloquial and even slangy immigrant American English used around the original $20^{\text {th }}$-century Roaring Twenties. On the other hand, the situation of My Life as a Spy is even more paradoxical: the book's Romanian version, promptly published by Vremea Publishing House in Bucharest, during the same year when it got published in the US, actually completes the American original book by means of a "second original" (or even some sort of a "clone", if one dare say so), in which the Securitate files are quoted in their true-to-fact versions. Whether in Romanian or in English, the infamous files are written in the Romanian blend of Newspeak, the dull duplicitous language, deliberately deprived of expressiveness, from George Orwell's Nineteen Eighty-Four. In other words, these books will forever float between our two languages, Romanian and American English, to prove their hybrid "nature", or rather their deep Doppelgänger status. ${ }^{3}$

3 It is never too late to remark on Katherine Verdery's admirable command of and fluency in Romanian, our archaic/awkward mother tongue. On the YouTube website, there are numerous rewarding recordings of Professor Verdery's recent academic conferences in our country, where she remains a most distinguished guest of honour. 
On the other hand, the challenge of My Life as a Spy is extremely complex for anyone ready to enjoy a book invoking polyphony from the very first pages: "This is a polyphonic work, incorporating the voices of the Securitate officers and their informers, my field notes and field index written at the time of my various research stays in Romania, letters I wrote home, people I interviewed for this book after 2008, and my ruminations on this material as I read it in the present" (Verdery 2018, xiii; my emphasis).

Although Verdery writes from the anthropologist's viewpoint and may not seem to be ever preoccupied by modern narratology, I was encouraged by her own notion of polyphony here, implying one of Mikhail Bakhtin's essential narratological theories. The Bakhtinian voicing concept is at home as guidance everywhere around in this recent American book about Romania, which goes beyond the frontiers of either document or fiction, back to the dreary historical past of the Cold War. Here one may also add the grotesque audio image of the foreigner's native language, which is bound to be mocked at whenever it is misunderstood, as this is represented in Bakhtin's dialogical essay "From the Prehistory of Novelistic Discourse”. Because Katherine Verdery has always had a gift for foreign languages, which has earned her well-deserved praise, she never regarded our (exotic) Eastern European land as a sort of Babylon.

And although in the end she emerges as a brave survivor of this double-sided research experience, Verdery's belated discovery of her own fake personae, clones, multiple selves, pseudonyms, code names, or conspiracy nicknames, from all her overwhelming eleven CNSAS files proves to her as poisoning morally as a virus. All these build a distorting labyrinth of an institutionalized gossip network, so harmful for the candid young researcher preparing her doctorate in 1973, then for the mature scholar returning and resuming her work in ill-omened 1984, and then again, for the consecrated academic, revisiting our country after December 1989, who eventually takes her chances to read the almost three thousand pages gathered about her by the Securitate officers and their dutiful informers in their Romanian blend of Orwellian Newspeak.

As soon as one has closed this book, the echo of its very first paragraph will bring it full circle:

There's nothing like reading your secret police file to make you wonder who you really are. Page after page, all your activities, all your motives, are subjected to a reading from an alien position embodied in a logic different from anything you recognize. Events you remember as significant might appear without comment, while others you thought unimportant burgeon into grounds for your expulsion from the country. (Verdery 2018, xii; my emphasis) 
Another Bakhtinian idea that suits my (amateur) approach of this singular volume is that of the unpredictable destiny of a book. Once the book is published, Bakhtin claims, the author can hardly influence its own chances into the world anymore. The book is like a grown-up child, facing its destiny beyond the author's/parent's best protective intentions. It is also in virtue of this Bakhtinian idea that Katherine Verdery's book has challenged me. And this bridges the gap between her book and Orwell's dystopia on the one hand and my own memories of 1984 on the other hand.

No other $20^{\text {th }}$-century dystopia can be more polyphonic than Orwell's Nineteen Eighty-Four. The terrible haunting voices from the ubiquitous telescreens would never prove thunderous enough to stifle/silence Winston Smith's endless inner monologue. This vocal juxtaposition results in a grotesque polyphony, yet never in anything like a dialogue. Strange as it may seem, this aspect of the British writer's book evokes so much of my adolescence and youth in Romania. And this same atmosphere of hallucinating real life is likewise so faithfully rendered by the American professor's memories of my homeland back in 1984.

\section{4 in Live Recording}

Resuming her anthropological research in Transylvania, Dr Katherine Verdery was back here again in August 1984, this time with an even more ambitious academic purpose: to study "the historical formation of national ideology" (111). She meant to find arguments in favour of her own theory: "my view that national identity is a conditioned historical effect rather than the foundation of human existence, as most Romanians (including many of its historians) believe" (118). Ironically, her vision is persuasive for me today, just by opening this kaleidoscopic book of her memories, surveillance reports, photographs - taken mostly without her permission. For me, this book represents now a confirmation of my own unbelievable memories of those Orwellian times in Romania. Fond of my books of literature, as I have always been ever since my adolescence, I might come to think such things never happened in our real lives but just in some great writer's dystopia, read a long time ago. And yet...

This interval is evoked in the volume's Chapter 2, "The 1980s: The Enemy's Many Masks". This time the author lives in Cluj, perhaps the most important city of Transylvania; she has a room at Hotel Continental, which is frequently searched in her absence by the Securitate. Her conspiracy name in this interval's surveillance files is "Vera". She is trapped between some of the people's friendliness, quickly responding to her own natural frankness, and some others' xenophobia, fuelled by the Securitate agents. Somewhere in her field notes she says: "there are three categories: people who are clean, securişti, and people 
passing as securişti. This really blows the mind" (Verdery 2018, 129; italics in the original).

Paradoxically, for some survivors like ourselves, Katherine Verdery's My Life as a Spy may be read now, in 2021, as the convincing evidence that desperately sought for "written record" of the past, for which Winston Smith craved in George Orwell's Nineteen Eighty-Four, the proof that such things had once actually happened. ${ }^{4}$

On the other hand, Orwell's Winston Smith's irresistible urge to start writing $a$ diary on a chilly day of April 1984, in dystopian London, seems to me to have lent something to (Verdery's) Vera's field notes of 1984-1985, in real Romania. Perhaps this is actually the first aspect that triggered my parallel between these two books, despite anything else. Winston's and Vera's eagerness to write down their candid innermost thoughts impresses me here and now as an essential expression of alienation. And my risky parallel is somehow confirmed by the inevitable final discovery of these intimate notes by the "wrong” reader: O'Brien - in dystopian 1984; the Securitate in actual 1984. And yet, in a strange way, these private/ professional notes were even meant to be read by the "wrong" readers: ironically, Winston had originally hoped O'Brien would one day read his diary, as either friend or foe. It is just that he mistook O'Brien for a friend, for a fatally long time. The same happened to real Katherine Verdery, in real Romania, in actual 1984. At that time, she was thirty-six years old; dystopian Winston Smith was thirty-nine.

Moreover, the same sharp contrast between Katherine Verdery's candid field notes and the infamous secret police files about Vera has always evoked in my mind the contrast/juxtaposition within the Orwellian dystopia between Winston Smith's desperate diary and his job at the Records Department at the Ministry of Truth (or "Minitrue"), where he was supposed to actually destroy any evidence of "real" life in London, Oceania; or at least "translate" such news into "Newspeak", much to the same outcome.

These two types of texts: the personal one and/versus the official one will run in an absurd parallel, thus explained by Katherine Verdery in her book:

A secret police file is the traces of a state creating a person; the "organ" (as they called themselves) for doing so in communist Romania was the Securitate. When I gained access to my file, I was able to see that process, to discover a reciprocal self-fashioning in which the Securitate made me a spy as I made myself an ethnographer, each act of creation influencing

4 Though we admire such classic studies of George Orwell's dystopia Nineteen Eighty-Four, as the Chapter 8, "The Last Intellectual in Europe: Orwell on Cruelty" of Richard Rorty's book Contingency, Irony, and Solidarity (1989), we deem a discussion of this in the present paper to be superfluous now. Likewise, Harold Bloom's essay on Orwell's postmodern novel in the volume Novelists and Novels. 
the other. Each of us sought anchors enabling us to define and classify our research object - for me, the peasantry of a Romanian village, and for them, "VERA". (Verdery 2018, 131)

In another one of Verdery's field notes, specific details of the terrible 1980s "austerity measures" can still ring a bell to some of us:

Field notes, 27 Jul. 1982

Romania has gotten a World Bank loan, whose condition is that there be no imports. This means that $60 \%$ of coffee sold consists of oats, so coffee is called by a name that means "neigh." No stockings, no sprays, because something in their manufacture has to be imported. No soap. As long as no imports, whole sections of factories are at a standstill, so the budget has to be wrung from the villages. The problem with wringing from the villages is that international treaty says no exporting of food if the local population is going hungry. Therefore rationing, which is supposed to be secret. General expenses keep rising. (Verdery 2018, 141; italics in the original)

Extremely responsive to whatever was going on around her, former "Vera" resorts now in her book to quotations from Romanian writers, such as Stelian Tănase or Herta Müller: "Novelist Herta Müller, writing of her relation to the Securitate in her book The Appointment, also captured brilliantly the insanity of the times. The book's last line: 'The trick is not to go mad'” (Verdery 2018, 142; my emphasis). But then, this was the very decisive impulse of Orwell's Winston Smith before starting his diary, on a fictive day of 4 April 4 1984: to defend his sanity.

As for the quotation from Tănase, this is a fragment Verdery took from his diary, eventually published in 2002:

Winter 1984-85, terrible and grotesque winter. Who can forget people's amazement that something like this could happen to them, that they should suffer so much? Lack of heat, no water in apartments, no heating gas. Driving prohibited for all vehicles but public transport. Food inexistent in the stores. Long lines, which last whole days and nights. So many dramatic situations. Old people and children, dead. Ambulances not circulating. The dispatcher asks you if the person is pregnant and about to give birth,

5 What she means here is our old "nechezol". Its traumatic taste would never fade from a keen memory: a fine "remembrance of things past", (not quite) in the line of Marcel Proust's dainty madeleine. This is almost too good to be true: here Katherine Verdery mentions "nechezol" in her book My Life as a Spy. There George Orwell mentions the ever smaller chocolate ration in his dystopia Nineteen Eighty-Four. It just goes to prove that there are books which can absorb us within until we come to wonder again about that frontier between fact (of a past forever remembered) and fiction (here to stay forever as a classic now). 
otherwise they refuse your call. They ask how old the person is, then refuse the call. What a time! What a nightmare! It's dreadfully cold in the house. The electricity is constantly interrupted, and electric heaters have been taken off the market. Someone is punishing us, is seeing to it that we die. (Verdery 2018, 142)

Surviving can be a gift, yet also a matter of practice. I remember that winter quite well; I was an undergraduate of our faculty, where I teach now. Some workers of the technical team made a joke in the spirit of the day by putting one paper cup full of water in each one of our classrooms. The water froze in all the cups, except for two. Just as Katherine Verdery mentions later in her book, students would attend classes fully dressed in their winter coats and hats and gloves. They took manuscript notes writing with gloved hands. These are such unforgettable crisis memories. It is a great comfort to find out someone else recorded them, likewise, in black and white.

In English, Tănase's book title is At Home They Speak in Whispers. File and Journal from the Late Years of the Dictatorship. This title is again true to fact. For who could dare to talk to anyone else but family members about obvious outrageous everyday life? And yet, Verdery also writes about the "rumours and queues" of "Cheauschwitz" - as people had come to call their homeland, in their typical vein of black humour. Here is another fragment from one of her formidable field notes:

Marina says winter in Bucharest was terrible; for three weeks running, there was no gas in her building at all, so residents drained the water to keep the radiators from freezing. The official reason for the cuts was to save industry, but coincidentally lots of old people died in the cold - she wonders whether that was part of the plan. Also - lots of infants - in three hospitals, all the incubators cut out. Marina's pregnant friend told her of a new law: it used to be that the father of the child would go to declare it at the civil registry on the day of its birth, but now he would go on the twentieth day, so statistics will not show all the infant deaths. Radiators in a number of schools burst during winter break and were not repaired by the beginning of school in February. Marina went to classes in a hat, fur coat, and gloves. She says there has never been anything like this in her lifetime. Diplomats from the French and Italian embassies were evacuated to Bulgaria and Serbia; before going, they protested officially to the Romanian government about their work conditions. (Verdery 2018, 143-144; italics in the original)

Obviously, Marina, Verdery's Romanian acquaintance, was a teacher at that time. As a female student at the time, I can also evoke here our weekly compulsory 
military training classes. Therefore, as a training infantry soldier, I was supposed to wear my clumsy uniform, which would hardly fit any young woman undergrad those days, once every week, to our classes with women officers and back home. Early in the morning, approaching the military school, one had to salute any officer one met down the way. One frosty morning of that gruesome winter, I was wearing my civilian thick fur hat instead of my shabby uniform hat, to keep my ears warm. I was on the bus. An elderly officer got on the bus, and I got instantly terrified: I could not salute him as I had no uniform hat on. The elderly gentleman pretended not to have seen me, it was such a kind expression of silent solidarity. Who knows, maybe he also had a daughter back home, embarrassed by the same absurd yet official situation.

In 1984 in Romania, George Orwell's dystopia was everyday life. At that time, Katherine Verdery may have been aware of the Orwellian Nineteen Eighty-Four or she may have not. Would that have been a warning of any kind to her against returning to our country? Anyway, Orwell's ominous masterpiece, though as if written with that Romania on the author's mind, was only unofficially known here. The grim 1949 prophecy had eventually come true, in a country where the book itself was blacklisted, wherefore its first published translation into Romanian was delayed until 1990, after the collapse of Ceauşescu's dictatorship. Therefore, the British dystopia only became well known to the Romanian readers at the same time with the "collective novel", The Woman in Red - likewise delayed by the local Thought Police censorship. No wonder why Romanian readers fell in love with both these forbidden books. At once.

Nevertheless, back in 1984, Orwell's dystopia did have a clandestine Romanian audience consisting of intellectuals who could either read it in the original English language or in any other major European language, whether German or French. It was a matter of luck. If you were fortunate enough, you found it in the original. If not, anyway, it was too exciting a chance to miss. I remember my first encounter with this book was then by means of a borrowed worn-out photocopy version translated into French. All the time I had was two days and one night with this forbidden book all to myself. I would not have missed it for the world. And I am positive that, had anyone told me back then that it would not be long before I got to teach this book, officially, at the same faculty where in 1984 I was still a belated student, I could never have believed it. This is a fact of historical truth: in 1984 in Romania, it was still too early for Nineteen Eighty-Four.

And yet the book belonged here, better than anywhere else, as it seemed to us all who could reach it despite the perverse unwritten law of dictatorship. And likewise against the self-doubt and uncertainty that were being inflicted on some of us by any possible means: from the general precarious living conditions and "austerity" (also experienced by Verdery here at that same time) to a certain category of young people's meagre chances towards self-assertion, by access 
to university studies. These young people were offspring of former so-called "enemies of the people".

Any kind of a further career that relied on freedom of mind, creativity, and the power of words was being carefully prevented by the state policy and its devoted Thought Police. The vast majority of Romanian young people back then were to become engineers. These "new" engineers were a cloning substitute of the entire former Romanian middle class. They would be safely provided with good endurable jobs, in the socialist factories and plants. They would be considered (the only kind of) intellectuals (needed in what was called the "multilaterally developed socialist society"). So busy with impossible, unrealistic production plans to fulfil, in all branches of a collapsing, ever more isolated national industry, they would hardly feel inclined to read or write, let alone think. They would mostly evolve into "good" Orwellian citizens, giving up their own lives, just like in Nineteen Eighty-Four, willingly adopting a grey routine instead of a meaningful existence; teaching their children the virtues of brainwashing obeisance to the unique national party. They were ever more numerous, influent, representing a cloning social élite. Anyone who wanted a safe better life for their offspring would advise them to study engineering. Indeed, they had the chances to get better off than the proles (i.e. Orwell's term for the working class in Nineteen Eighty-Four), who were in fact their own parents in most of the cases.

On the other hand, in actual 1984 socialist Romania, there were ridiculously few undergraduate students of philology - especially letters; of philosophy - which only mattered as socialist doctrine; of history - which was being continually denied, outrageously transformed overnight according to the ideological plan of the unique Party; of law - distorted and repressed in virtue of the same policy; of sociology - perverted into some discipline to serve the same absolute control purposes; of journalism - which was only accessible to candidates ready to pay lip-service to the dictatorship and play the obscure game of the day. It goes without saying that all these fields and disciplines of academic study, specifically related to the freedom of mind, creativity, and the power of words, were attentively supervised by the Securitate. It goes without saying, too, that anthropology and ethnography belonged together under this same umbrella. Hence the particular intensity of the clashes between Katherine Verdery and her eager Security spies. If we just add to it their specific xenophobia, the eleven surveillance files on her account are quite easy to explain.

Just like in Orwell's dystopia, in real Romania, the past was grossly changed and history was being blurred to please the Party and Big Brother. The few successful university graduates would confirm their reliability and further on write and publish diligently in Romanian Newspeak - a nonsensical idiom popularly known as "wooden language". Most of these few pseudo-intellectuals came from families with "clean files", of "sound social origin". Therefore, failing 
at least the first attempt at an entrance examination, to any one of these faculties, ideally having to deal with the freedom of mind, creativity, and the exquisite power of words, plus the faculties of arts: visual arts, music, drama, and film studies, was quite a common experience among the other daring candidates who lacked the basic quality of the "clean file". It all depended on their parents, who had been themselves victims of the same system. Mine has been an exceptionally fortunate case: I owe it all to my mother, who would never let me fall prey to selfdoubt and uncertainty. As we can see, whether for an American scholar visiting us or for a Romanian scholar "born here of parents born here from parents the same, and their parents the same" (Whitman 2013, 23), writing about Romania has never been easy.

The CNSAS files discovered and quoted by Katherine Verdery attest to precisely the fact that inoculating self-doubt and uncertainty has always been a well-defined purpose, an end in itself, persistently aimed at by the Romanian Securitate or by any other surveillance institutions, by means of specific psychological techniques of intimidation, demoralizing, or misinformation. This should not surprise anyone: ever since 1949, when it got first published, Nineteen Eighty-Four would anticipate this infallible policy of the unique Party, prevailing over almighty Ingsoc ministers such as: "Minitrue, Minipax, Miniluv, and Miniplenty" (Orwell 1977, 7).

There is also a certain American side of Orwell's intricate (and even lyrical) dystopia, a book which is perhaps too famous for its own good and nowadays quite often misinterpreted, if not downright abused. Firstly, in this nightmarish fantasy, the terrible map of Oceania, the horrific homeland of London-born Winston Smith also includes the original/former USA, besides the original/ former UK. If there were any room for Romania left, this should be somewhere lost in Eurasia, as this dialogue between Winston Smith and O'Brien shows:

"You are not even masters of this planet. What about Eurasia and Eastasia? You have not conquered them yet."

"Unimportant. We shall conquer them when it suits us. And if we did not, what difference would it make? We can shut them out of existence. Oceania is the world." (Orwell 1977, 213; my emphasis)

Secondly, Orwell's “Appendix, The Principles of Newspeak”, often included just by itself in the most prestigious contemporary anthologies of literature, makes direct reference to the Declaration of Independence, the (now romantic) birth certificate of the United States of America, sarcastically dismantling it. And this quotation from the Declaration of Independence is employed to illustrate the virtues of Newspeak in which no thoughtcrime/crimethink should/could survive: 
We hold these truths to be self-evident, that all men are created equal, that they are endowed by their creator with certain inalienable rights, that among these are life, liberty, and the pursuit of happiness. That to secure these rights, Governments are instituted among men, deriving their powers from the consent of the governed. That whenever any form of Government becomes destructive of those ends, it is the right of the People to alter or abolish it, and to institute new Government. . . . It would have been quite impossible to render this into Newspeak while keeping to the sense of the original. The nearest one could come to doing so would be to swallow the whole passage up in the single word crimethink. A full translation could only be an ideological translation, whereby Jefferson's words would be changed into a panegyric on absolute government. [ . . . ] It was chiefly in order to allow time for the preliminary work of translation that the final adoption of Newspeak had been fixed for so late a date as 2050. (Orwell 1977, 251; emphasis in the original)

Ergo the year envisaged in Nineteen Eighty-Four for the absolute triumph of Newspeak is 2050: it will not be long now, would it?

\section{The Books We Read}

"The best books, he perceived, are those that tell you what you know already" (Orwell, 1977, 161). This is one of the numerous paradoxes the reader may encounter in Winston Smith's inner monologue. We may still hesitate as to what to make of it: either take it as an ultimate metafictional witticism, comprising within itself the nameless reader's own reflection, or consider it as a warning against the most insidious mental manipulation of the Thought Police.

Therefore: what are we looking for in a book? Is it absolute truth? Is it instruction, information? Is it a certain pleasure of the mind, imagining a silent, secret dialogue with a much admired author?

"Et in Arcadia ego." I know 1984: I have read the book, I once was alive, then and there. Or rather "I am the man, I suffered, I was there" (Whitman 2013, 57).

Neagu Djuvara was himself no poet. He was an exquisite Romanian historian, a man of the world in the very best of all possible meanings; a lucid thinker and experienced traveller blessed by an exceptionally long lifespan and likewise a sharp sense of humour. Rounding up one of his bold books of the early $21^{\text {st }}$ century, entitled by a rhetorical question Is There Such a Thing as True History?, the venerable scholar concludes: 
To sum up, this is the awkward fate of a historian: he has to content himself with the thought that his work can never render an everlasting building but just a brick or some wall corner of a building ceaselessly crumbling, as in Master Manole's legend; still a building which we are doomed to go on building, endlessly, as in the myth of Sisyphus. And if ever, once in a hundred years, due to some absolutely exceptional talent, any historical piece of writing still survives, its chances to eternity intact, then the survivor in its author shall be rather the Poet than the Historian. (Djuvara $2004,137)^{6}$

It is Plato who first believed that somehow poetry is nearer to truth than history. There may be a certain spiritual affinity between the two thinkers: the ancient Greek philosopher and the Romanian historian, miraculously also our contemporary for a while. Both pertain to the Balkans, a cultural zone so frequently fallen under big question marks - on the cultural map of the world, a zone of continual conflict and crisis.

The daring American protagonist of Katherine Verdery's first-person narrative grows up (also) in this dangerous place, so far away from her home, bravely approaching it all by herself. Her intellectual generosity and story-telling gift are evident. She may be boldly riding a Mobra motorbike instead of sailing on a raft down the Mississippi. But the spirit of Huckleberry Finn, at once candid and curious, vulnerable and confident, runs in the family. And, having read her book now, we can paraphrase Mark Twain's most popular anti-hero: we have (all) been there before.

\section{Works Cited}

Ascherson, Neal. 2018. "Don't Imagine You're Smarter”. London: London Review of Books vol. 40, no. 14, 19 July.

Bakhtin, M. M. 2004 [1981]. The Dialogic Imagination. Ed. by Michael Holquist, transl. by Caryl Emerson and Michael Holquist. Austin: University of Texas Press.

Bloom, Harold. 2007 [2005]. Novelists and Novels. New York: Checkmark Books. Djuvara, Neagu. 2004. Există istorie adevarată? [Is There Such a Thing as True History?]. Bucharest: Humanitas.

Doyle, Arthur Conan. 2003 [1986]. Sherlock Holmes: The Complete Novels and Stories. New York: Bantam Classics.

Müller, Herta. 2001. The Appointment. A Novel. New York: Metropolitan.

$6 \quad$ My translation from Romanian. 
Nedelciu, Mircea, Adriana Babeti, and Mircea Mihaies. 2011 [1990]. Femeia în roşu [The Woman in Red]. Iaşi: Polirom.

Orwell, George. 1977 [1949]. Nineteen Eighty-Four. London: Penguin Books.

Poe, Edgar Allan. 2009 [1849]. The Complete Illustrated Works. London: Bounty Books, Octopus Publishing.

Rorty, Richard. 1989. Contingency, Irony, and Solidarity. Cambridge: Cambridge University Press.

Tănase, Stelian. 2002. Acasă se vorbeşte în şoaptă: Dosar şi jurnal din anii târzii ai dictaturii [At Home They Speak in Whispers: File and Journal from the Late Years of Dictatorship]. Bucharest: Compania.

Twain, Mark. 1994 [1885]. The Adventures of Huckleberry Finn. London: Penguin Popular Classics.

Verdery, Katherine. 2018. My Life as a Spy: Investigations in a Secret Police File. Durham and London: Duke University Press.

2018. Viața mea ca spioană: investigații dintr-un dosar de Securitate. Bucharest: Vremea.

Whitman, Walt. 2013 [1892]. Leaves of Grass. New York: Signet Classics.

Wilde, Oscar. 1991 [1891]. The Complete Illustrated Stories, Plays and Poems. London: Chancellor Press. 